\title{
RBPORT
}

of

Committee on Theris

The undersigned, acting as a Committeo of the Graduate School, have read the accompanying

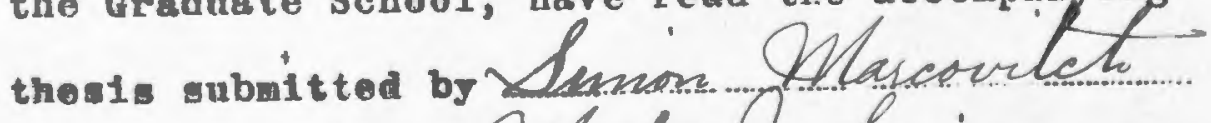

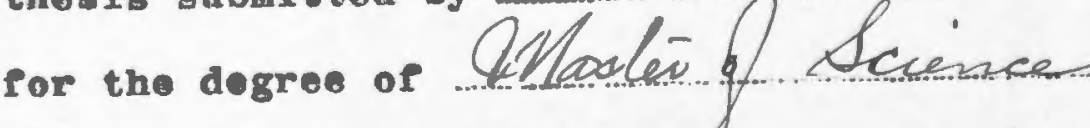
They approve it as a thasis leeting the requiremente of the Graduate School of the Unirersity of yinnesota, and recommend that it be accepted in partial fulfillmont of thy roguironote for tho degree of

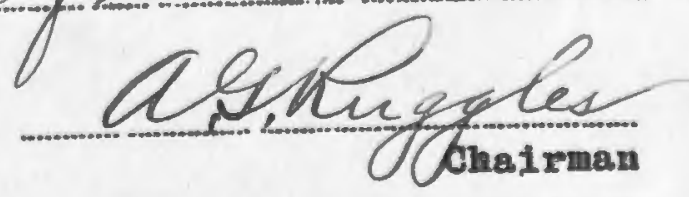

Mllog 29, 10016

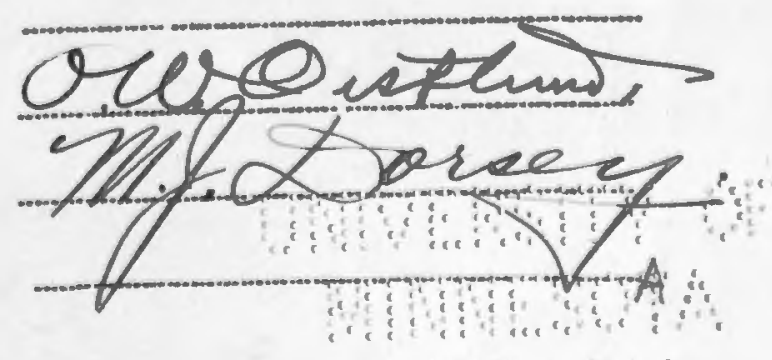

\& 


\section{THE STRAWBERRY WEEVIL}

in MINNESOTA.

A Thesis submitted to the Froulty

of the Graduate School of the

UNIVERSITY OF MINMESOTA

by

SIMION MLARCOVITCH

in partial fulfillment of the requirements

for the degree of

Master of Solence

June

1916. 


\section{AOKHOWLEDGZIOES}

I wiah to exprese my appreolation to Profeasor $71111 \mathrm{am}$ Noore, at whose suggeation the work was undertaken and, for many valuable auggestions in the aourse of the study. 
Summary

Classification and Symonomy

History and Distribution

Losses

Food Plants

Technical Description

Life History and Habits

oriposition

E86

Larva - habits of

Feeding habits of Adult

Extent of Infestation

Season History

Bibernation

Natural Enemies

Control

Bibliography
1

4

5

5

6

$\eta$

9

9

13

13

14

16

17

18

21

23

27 


\section{THE STRAWBERRY WEEVII IN MINNESOTA \\ (Anthonomus signatus Say).}

\section{Summsry}

1. A shortage in the number of blossoms is the first indication of the presence of the weeril.

2. The injury of this insect is due to the severing of the buds after oriposition, for the protection of the larra within. From 40 to $85 \%$ of the crop may be thus destroyed. 3. The strawberry weevil may be distinguished from other weevils in the beds, by the presence of two dark spots, one on each wing cover, and by its diminutive size, being about $1 / 10$ inch long.

4. Adults appear betweon April 28 and May 5. Egg stage arerages five or six days, larval, twenty to twenty-five dajs; entire life cjole about thirty-four days.

5. The eggs are laid within the bud; where the larva feed on the contents within - principelly the pollen; pupate within the fallen bud.

\section{During oriposition, the adults feed principally} on pollen which is likewise the principle food of the larra so that only the staminate varieties are usually injured. The new brood upon emerging in the summer were found to eat the leaves making numerous small holes on the under surface. Upon coming out of hibernation in the spring the beetles feed in a similar manner.

7. The older beds are more seriously in jured then the 
newer ones.

8. The beetles were found in large numbers hibernating on August 25, 1915 in the strawberry beds among the dead leaves, and on the ground about the plants beneath the leares. They were also found hibernating underneath the straw on April 18, 1916

9. The natural enemies reared were the chaloids EupeImus coleopterophagus

Catolocous perdubius

Habrocytus obscuryses

Yolvmeura consobremis

Earrtoma $\mathrm{sp}$. and Iestodiplosis sp. of the family Cecidomyidar.

Control

10. With the one-crop system, injury can probably be done away with entirely.

11. All bady infested fields should be plowed under immediately after pioking.

12. One or two rows of the old field should be left uncovered and used as a trap orop, and plowed up when the beetles oongregate on them.

13. Leere the mulch or cover on as long as possible in the spring, so as to force the weeril to the trap rows.

14. Covering of the beds with muslin ald not prove sat1sfactory.

16. Spraying with poisonous arsenioals in the spring is of little value, because the leaves 110 so $10 \mathrm{w}$ that apraying on the ander surface is impossible, and because the adults feed 
principalig on pollen at that time.

Spraying in the summer, when the new brood emerges, will probably be found much more effective. 
Introduction.- If during the blossoming season of the strawberry, there appears to be a shortage in the number of blossoms, the strawberry weeril may be suspected. Where this insect is at work the buds will be found severed from the stem, some having dropped to the ground, while others are still attached by a few shreds in a drooping manner, ready to fall. Further examination around the buds may reveal a small snout beetle which is the cause of the injury, and which is marked with two dark spots, one on each wing cover. The females oriposit in the buds, after which operation they cut them off, in order to proteot the larva within. (Fig. 1, PI. 1.) As few farmers are aoquainted with this insect due to its diminutive size, the shortage of blossoms or berries is usually attributed to frost, hail, or to some other agenoy.

Clessification and Synonomy.- This insect

belongs to the suborder Rhyohophors or snout beetles, constituting a large and important group of beetles comprising some of our most important insect pests. In the genus snthonomus, to which the strawberry weevil belongs, we find such notable pests as the cotton boll weeril, A. grandis, the cranberry ourculio, A. suturalis, the apple curculio, $\Lambda$. quadribbus, the strawberry and apple blossom weeril in Fagland, A. rub1 and A. pomorum, respectively.

In 1885, Prof. Riley considered signatus 1dentical with musoulus, which name appeared in the literatare of the strawberry weevil until Mr. Chittenden in 1897, upon the appearance of Dr. Deitz' paper on the Anthonomini identifled the species as A. Bignatus. A. musculus is amall and less robust, the 
second joint of the female is scarcely longer than the third, and according to Dr. John Hamilton, is found only on huokleberry, and rarely after the first week in June, whereas signatus is found on various plants and shrubs, such as Rhus, Tilia, and Rosacere. History and Distribution.- The strawberry weeril is a native species, widely distributed, and was first reported as injurious in 1871 by hir. Townsend Glover, at silver Hill, Maryland. Since then, it has been reported from Missouri, 1873; Michigan, 1883; Staten Island, 1885; New York, 1886; Ontar10, 1886; Quebeo, 1887; Pennsglrania, 1888; Virginia, 1891; New Hampshire, 1891; De1\%̆ware, 1892; New Jersey, 1893; and North Carolina and Ohio in 1893.

In Minnesota this inseot is first mentioned in Iuggür's Fifth Report in 1899, as occurring in limited numbers. The insect is again mentioned by Washburn in 1903 and 1904. During the past two years, the weevil has appeared in such injurious numbers as to warrant further study of this insect.

Altho the weeril is very abundant at Hopkins, Minnesota, and in the vicinity of st. Paul, farmers have not reported it as being injurious in other parta of the state, due possibly to the fact that most growers are ignorant of this insect. The weeril was found as far north as Duluth by Mr. Vallear, outting the buds of wild strawberries in great numbers, while the writer has found it at stillwater. It is probably distributed over the entire state, wherever strawberries are grown.

Losses. When the strawberry weeril is pres- 
ent, It undoubtedly infliots serious losses, as it appears in large numbers in the early spring, cutting the most mature buds which would be the first to ripen and therefore the most raluable. In Virginia and some of the other southern states, the writer learns that many truok growerg have abandoned the growing of strawberries, due to the work of the weevil. At Hopkins, one farmer reports a jield of twenty-two crates this year while from a similar patch, a few years ago, he obtained one hundred twenty-I1ve crates. Altho some of this 1088 was due to winter-killing of the plants, the weevil is responsible for the greater share. At another farm 90 per cent of the buds were found cut.

Food Plants.- The weevil seems to be confined principally to buds of the family Roseacea, having been reported as attacking the wild atrawberry; black raspberry, blackberry, devberry, red raspberry, rose, flve-finger potentela oanadensis, and Cercis canadensis, and have been taken on Tilia, Rhrs, and Monarda fistuloge. From my own observation, I found the weeril cutting the buds of the wild strawberry, dewberry, and red raspberry, especially hte latter (Fig. 1, PI. 2). Blackberries near by were not injured.

Among the oultivated strawberries, the Donlap is the most widely grown in Minnesota and the one that 18 generally attaoked. In faot, at Hopkins, no other variety was found to be used, except sometimes the Warfield which is a pistillate form. As 18 well know, the weoril is restrioted to the staminate varieties and these which furnish considerable pollen, since this con- 
stitutes the ohief food supply of both larrae and adults. Adult.- Original Desoription.- A. Eignatus.

"Body with numerous, prostrate, white hairs: rostrum longer than the head and thorax, slightly arquated, linear, lineated: scutel oral; elytra sanguineous, with punctured, impressed striae; region of the scutel to the middle of the suture, and band of three large, unequal spots behind the middle brown."

Desoription after Dietz. A. Signatus.-

Robust oral, piceous; elytra red, denuded fascia, and soutellar space darker, thinly clothed with whitish pubescence. Beak moderately slender, feebly curved, subopaque and rather densely striatopunctate; median oarina smooth, distinot. Antenna testaceous, club darker, funicle rather stout, outer joints distinctly wider, second joint distinctly longer than the third, but not slender; foints 3-7 transversely rounded. Ijes moderately convex, free behind. Head convex, occiput somewhat shining, front with a few remote punotures, finely and indistinotly rugulose, frontal puncture distinot. Prothorax wider than long, moderately narrowed in front; sides not strongly rounded, feebly constructed at the apex and traneversely impressed behind the anterior margin; surface rather coarsely and densely punctured, pubescence condensed along the median line. Elytra less than one-fourth wider at the base than the prothorax and about onehalf longer than wide, a little widened to behing the middle; sides feebly rounded; striae impressed, punctures moderately large, close set and becoming emaller towards the lateral margin; interspaces slightly convex, shining with an irregular row of 
fine punctures; the denuded fascie extends from the side to the third interspace, another denuded spot on the second interspace: soutellar space and along the suture darker; scutellom and intrahumeral spot densely pubescent. Thorax underneath more densely clothed with white, squamiform pubescence. Abdomen sparsely pubescent, segements transversely strigose, first and second segments rather long. Legs slender, femore feebly clavate, piceous, all armed with a sharp, well-marked tooth; tibiae paler, anterior feebly bisinuate, middle and posterior nearly straight, tarsi pale, first joint elongate. Long. 2-2.9;m; .08-.12 inch." Pupe.- Length $2.3 \mathrm{~mm}$. bf $1.5 \mathrm{~mm}$. wide. Color creamy white. The ejes are the first to turn to a dark-redalsh oolor, while the mandibles and tarsal claws show thru the pupal skin. A little later the proboscis and elytra become darker than the reat of the body, and a day or two before emerging, the pupe becomes derk-colored. The beak rests on the venter of the body with the legs drawn up at the sides. The eljtra curve towards the venter. A round spiracle is visible just below the eyes. The hairs appear to rise from small tuberoles, there being a pair of very small ones just above the ejer, with a larger pair between the ejes. Another pair of hairs is found on the beak just above the insertion of the antennes, with a minute pair farther down the beak. There are three pairs on the prothorax just behind the head, a large pair on the mesoscutum and four pair on the netascutim.. The lateral spines on the abdomen are more prominent than the others. The last adominal segment is produced into a pointed process bearing two prominent brownish 
spines (k'ig. 5, P1. 5).

Iarra.- Iength $1.7-2.2 \times 1 \mathrm{~mm}$. wide.

Width of head $2 / 5$ to $3.5 \mathrm{~mm}$. Color greenish white or whitish, sometimes mixed with patches of reddish-brown and forming a reddish stripe on the dorsum. Nearly oylindrioal but slightly flattened on venter, with the abdomen curved ventrally. Anal segment somewhat lighter in color than the others. The dorsum strongly winkled, with the venter smooth. When nearly ready to pupate, the larva becomes cream-colored, swellings appear on venter of thorax and the body becomes straighter. The dorsum of each thoracic segment is composed of two folds while that of the abdomen of made up of three folds. Head about as long as broad; light-yellowish; front yellowish; epistome and mandibles darker; epicranial suture extending nearly to epistoma. Antennae minute, one-jointed; situated at base of mandible. The latter dark-brown; bidentate. A small blaok eje spot lateral of the antennae. Body of larva covered with many fine hairs (Fig. 4, 1.5 ) The Egg.- The egg messures about $.55 \mathrm{~mm}$. in length by $.40 \mathrm{~mm}$. wide and is elliptical in form, altho the shape and size varies considerably. It appears smooth with no visible markings (F1g. 2, PI. 5).

Life History and Habits.

\section{Oriposition}

Bramination and Selection of Unlnfested Bude.Oriposition was observed several times and found to take place in the following manner:- The female crawls about a nearly 
matured bud examining it carefully with her antennae. After a period of from one to two minutes, a spot is selected, usually at the base of an upright sepal. If the bud is already cut, with an egg inside of it, she refrains from ovipositing in 1 , and passes on to examine ohitter buds that have not been cut, altho two and even three eggs heve been found in a single bad at a time when the beetles are abundant and meny buds are being out. If two or more hatch in a bud, one is very apt to destroy the other, so that only one larva develops.

It is, therefore, of very great importance to the reproduction of the weeril to select uninfested buds, as this insures the most farorable conditions for the maturity of the largest number of offepring.

Place of Eg8 Deposition.- The spot selected for the ege puncture is usually in the crevice and at the base of an upright sepal, being a little above the middle of the bud. In a few instances, egg-laying punctures were observed to be made below the midale of the bud.

\section{The Act of Oriposition.- The favorite pos-}

ition of the weeril in arilling a hole thru the oalyx, is with its head towards the base of the bud. Having obtained a firm position, she proceeds to drill the hole with her tiny mandibles. With an up and down motion, the hesd is thrust into the bud where a place is cleared for the egg and some feoding on the anthers takes place. After this operation is finished she withdraws her beak, turns about, and places the tip of her abdomen directly orer the puncture, into which the ovipositor is protruded. When 
the egg has been ingerted into the bud, the ovipositor is withdrawn and the beetle proceeds to eut the bud; the female will sometimes turn around after oviposition and poke the egg in with her snout. If the beetle is disturbed during the process of drilling the hole, It remores its snout, rests on one side of the bud, and completes the hole when the disturbance is over. Sometimes the female will fail to locate the hole with her ovipositor. She then rune back and forth over the bud nervously hunting the hole with her antennae and if successful thrusts her beak into the same puncture for a few minutes to make sure of the right place. The beak is then removed and oviposition is again attempted. This process may be repeated several times.

The severing of the Bud.- Cramling down to the base of the bud, she begins to sever it from the stem, sbout $1 / 16$ in. from the base of the bud, altho stems have been found out at various distances up to one inch from the bud. In doing this, she places her hind legs against the base of the bud, (Fig. I,Pl.1) while the middle and front legs rest on the stem. As the beak sinjo into the stem, the fore-legs are spread watil they nearly clasp the stem. The stem is cut either straight across of more usually obliquely (Fig. 1, P1. 2). Enough of the stem is cut, so that the circulation is cut off and the flow of sap arreated, the cut ond turning black after a short time. Either soon after or within a fow days, the bud droops, discolors, and finalig falls to the ground.

Time required during Oviposition.- Observations on the time for making the egg-laying punctures varied from 7 to 
12 minutes, with an arerage of about ten minutes. The time required to lay the egg varied from 30 seconds to two minutes, While the outting of the stem varied from ten to forty-five minutes, according to the thiokness of the stem. In the latter oase, the weevil having started so obliquely, ran into the bud proper, so that it could not cut it completely. At the time,a male was sitting on her back and perhaps distracted her.

\section{Making puncture}

$10 \mathrm{~min}$.

$11 \mathrm{~min}$.

$10 \mathrm{~min}$.

7 min.

Averago $9.5 \mathrm{~min}$.
Iaving egg

1 min.

2 min.

$3 \mathrm{~min}$.

30800 .

1 min.

\section{Cutting bud}

27 min.

13 min.

20 min.

45 min.

19.6 min.

The Egg-laying Period of the Female.- A fair

average for oomplete oviposition, from the time the female begins to hunt for a suitable place to oriposit until the bud is cut, appears to be about 32 minutes.

Mr. Theobald reports that in oase of the apple blossom weevil, oviposition takes about three-fourths of an hour, so that in fine weather when the blossom buds expand rapidy, a single female cannot lay very many eggr. In cold and unfevorable weather then, the weovil is more injurious in England, because the opening of the buds is retarded. The same faot appears to be true of the atrawberry weevil, since it is very similar in habits.

Flight - Pleying Possum.- When disturbed, the weov1l raises its antennae and stands still. If further dis- 
turbed, it drops to the ground and ourls itself up. Jpon being disturbed further, it slowly gives up the possum habit and crawls away, but will sometimes take flight.

Flight appears to be in a horizontal direction, the beetle having never been seen to fly upward. The distence covered varied from four inches to three feet. The males fly muoh more readily than do the females, in fact no females were observed to fly.

Copulation.- Copulation was observed to take place for about five minutes, altho the male will often ride around on the baok of the female for a much longer period. Their bodies during this act are at right angles to each other, while the tips of their abdomens are together.

The Egg.- Upon opening a bud, the egg is found to lie loosely among the anthers or against the petals, or upon the receptacle, a little to one side of the egg punoture. (F1g. 1, PI. 5). About a day before the egg hatches, the mandibles cen be clearly seen thru the chorion, moving beok and forth. Hatching.- The period required for an eg8 to hetch was found to vary from three to nine days, depending entirely upon weather conditions, averaging about five or six daye.

\section{The Iarva}

Habits of Larva.- To free 1 tself from the $\theta g 8$ ohell, the larva wriggles and oontracts, pushing out its mendibles until it is free from the eg8-8hell.

One egf was observed to hatch on May 5. The 
young larva was then placed in water where it lived for four days. Upon hatching, the larva is whitish, with a jellowish head and dark-colored mandibles measuring about $3 / 5 \times 1 / 5 \mathrm{~mm}$. The first food is the pollen, and being a very nutritious food, it grows rapidiy. Later it begins to attack the petals, pistils, and receptacles. In about a week's time, the larva will measure $1.5-2 \mathrm{~mm} . \times 3 / 5 \mathrm{~mm}$. At this time, the head is of a lightyellowish or greenish color with dark-brown jaws. The body has a flaky appearance with areamy white spots, mixed with orangereddish patches, forming a distinot brownish line on the dorsum. There is less red on the thorax and anal segments.

On May 20th, some buds that were collected April 29th, were found to be entirely eaten out, nothing remaining but the sepals (Fig. 3, P1. 5). The last thing to be eaten is the receptacle in whioh the larva makes a considerable dopression. On all sides of the larva and filling the bud, the shreds of excrement are to be found, some of which forms a hard and tight cell about the larva, so that on opening a bud, it sorretimes appears as if the larva was not present until the cell is broken open.

\section{The Adult.}

Feoding Hebits.- On May 5, 1916 the weevils were found present in large numbers in an old patch and the young tender leaves conspicuously dotted with small punctures on the under surface. The leaves are close to the ground at this time, and spraying the under surface of the leaves would be impracticable. In a new patch 120 feet away, neither beetles nor feeding panotures 
could be found. When the bude become more mature, the greatest share and the most important food of the adult weevil is upon the pollen within the buds. In one instance a beetle was found with his snout in the bud, olear up to the eyes, with the funicle of the antennae in the groove of the snout so that only the club is seen to project backward.

They also feed on the petals, after the buds open, making small round holes and to some extent, at the bases of the sepals and the tissue from which the anther filaments arise. In some cases, the filaments were girdled by their punctures so that later they turn brown.

On June 16th, four weevils that had emerged the day previous were confined in a wire cage over a strawberfy plant. The bude had all opened so they had nothing but leaves to eat. In a few daye, the lower epidermis of the leaves was found full of small consplouous round holes (Fig. I, Fl. 6), and one of the leaves that was badly eaten was found drooping. In a ripe berry, two weevils were found in a large cavity where they had been feeding (Fig. 3, Pl. 6). In the fleld, however, they do not attack the berries to any great extent, altho a few were found with holes characteristic of the weevil.

Some old weevils also confined in a cage made the same holes in the lower epidermis, but to a lesser extent. Recently emerged weevils when confined on June 28th, were found to heve cut a few buds, but no egge could be found in them. On July 14, leaver with characteristic holes of 
the weevil were found in the field; while on August 11, in a field where the weevilo were very abundant, the leaves were conspicuously dotted with the tiny holes of the weevil, similar to one shown in the photograph.

On cloudy and rainy dags the weeril rests quietly among the stems near the crown or beneath the buds. Sometimes they are found within the crown or on the ground near the crown.

Extent of Infestation.- After careful observation in many of the fields, it was found that the older the beda, the more heavily infested they were found to be. Plants set out the same spring do not seem to be attacked. Last year, the weovils were so numerous that the growors say they were equally destructive both on the ner and the old fields. On a patch of berries uncovered early and in full bloom by Neay 5, no weevils were found present, due to the fact that it was a new patoh set out the previous year.

A new patch of berries surrounded by grass land was found to be in almost perfect condition, only one or two buds being found cut. In another field, on June 7 , about 60 per cent of the buda were cut on a two jear old patoh, while on a new patch separated only by a small blackberry patoh, little injury wes shown. The writer visited many flelds and in all cases found those beds from which the firet picking was to be made, muoh less injured. This is in acoord with the hibernation habits of the adults, which winter over in strawberry beds. 
On May 2, an ege was placed in a pill box and hatched on May 10. The larva pupated on May 30, the adult having emerged June 5. In buds collected on April 29, many pupae, together with one adult, were found on June 2. The entire life cycle eppears to be about 34 days in ihinnesota.

In the fleld, however, it was not until July 1 , that pupae together with a few adults were found commonly.

In the insectary pots, both the weevils and parasites were emerging in large numbers on Jaly 8 , while a few were even coming out on July 25.

\section{Seasonal Hiatory.}

Time of Appearance of Betlea in Spring.- The first buds found to be out were in a single old uncovered row on April 20, 1915. Many bude were already in blossom in that row, being at least one week or ten days earlier than those that had been covered. On April 30, 1915 many of the buds were cut in that row, and the weevils were found feeding and ovipositing in a nearly-mature bud.

This seems somewhat early for their appearance In linnesota, for a period of about two weeks of warm weather appears to have brought them out of their hibernating quarters. In 1916, the beetles were observed on the planti on May 5th, but no buds out; However, from May lat, 1915 and thru the whole month of May, excepting a few days, a period of cold, wet and rainy weather set in. Two rather heavy frosts ocourred, May 9th and May 17th. On the latter dato, altho a heavy snowstorm 
oocured the larvae were not killed in the buds.

By May 9th, the weevilo were found fairly

numerous on a two-year-old patoh, altho on the new patches they were not jet to be found. On the same day the buds of a wild strawberry plant were found out.

On May 12th, buds were found out in some of the new patches, while in the old single row, a great many were already cut. It appears that, from this date, and on, the weevils do most of their work. By May 17th, the weevils were present in great numbers and rapidiy increasing and appearing in the new patches.

On June 2d, the weevils were perticularly abundant on a two-year-old patoh, while on June $7 \mathrm{th}, 85$ per cent of the buds appeared to be out. The weevils were found to have out many bude of the red raspberry on June 7 th, but did not harm the blackberries that were near by.

On June 14th, and June 20th, the weevils were still cutting buds while on August 11, some weevils were jet present in the fields, both on strawberry and raspberry.

No weevils could be found on the plents on

Argust 25th.

\section{Hibernation}

Concerning hibernation, Wr. Sherman at North Carolina writes in 1904 as follows:- "As yet it is impossible to say definitely just how and where the inseot passes the winter. It seems certain that they winter in the adult atage, and it also seems oertain that they hibernate around the edges of the fleld 
or in woods, but exactly where, whether in stumps, rotten logs, under brush, rubbish, and leaves, or under the surface of the ground, remains a question. Two whole days of careful searoh on March 9 th and 10th, looking under bark, sifting dirt, trash, pine straw, etc., falled to throw any light on this question."

In New Jersey, Professor John B. Smith, reports in 1911 as follows, on hibernation. "The results were not oncouraging. Specimens in small numbers were found in almost all the places tested, but less in the stramberry fields themselves, than in the rubbish around the edges. They leave the strawberry fields after thej mature, beosuse they are more disturbed there than elsewhere and because it is too exposed and sunny in midand late summer. For shelter any rubbish-oovered, moist, protected locality will answer and nothing seems more attractive than the edge of wood or scrub land, if such is near by."

On September 20, 1914, a whole day was spent in the fields to find the insect in the hibernating stage, but with ho success. On September 30, 1914, another unsuccessful search was made. On sugust 25, 1915, however, the beetles were found hibernating on the ground around the crowns or beneath the dead leaves. When disturbed, they orawled lowly away.

On 0otober 1st, the weevil was again found

hibernating in large numbers among the dead leaves beneath the 3trawberry plants. About 20 weevils were found within one-quarter bi an hour, showing clearly that most of them are to be found in and among the dead leaves. By pioking up a handful of the dead 
leaves, and examining them carefally, four or five weevils were often found. They are also found on the ground beneath the leaves and around the erown of the plant. They do not appear to be present under sticks or stones between the rows, but always well protected under the old leaves. Search was made around the edges of the field and within the woods nearby, but no weevils were found. On April 18, 1916, the weovils were agein found hibernating while the cover was still on the plants. By remoring the straw, and examining the dead leaves carefully six weevils were found in about thirty minutes. Some of the beetles were lying on the ground atill dormant, while others were crawling about very slowly.

Another fact whioh would tend to confirm that the weevils do not hibernate within the roods in Minnesota is that on May 1916, the weevils could be readily found in the old patches and feeding on the leaves, while in the new fields even tho they adjoined a woodlot, careful search failed to reveal their presence. The plants were equelly meture in both fields, so that it is diffioult to tell why they should not be present in equal numbers if they migrate from the woods in the spring. The weevils, at lesst in Minnesota, hibernete within the strawberry fields and not in the roods, as was thought; altho it is possiblo that a few might happen to migrate to the woods.

\section{Intermittance of the Weevil.}

Mr. Chittendon remarks:- "It is fortunate also that this weevil like so many other troublesome spesies is more or 
less intermittent in the character of its attack, appearing in great abundance for one or more seasons in certain districts and showing a vast amount of damago, and then without any apparent reason relapsing into comparative obscurity only to reappear after a number of years and in perhaps some new locality."

From a study of the hibernation habits, the intermittance of this insect may perhaps be explained by the fact that sometimes a farmer may have all old beds, which would be plowed up at the end of the season to start with new beds the following year. As the beetles migrate slowly, the new beds would be comparatively free, because most of the weevils were probably killed by being plowed under the previous season.

Another factor is the character of the season, as was explained in a previous paragraph. In fine weather, when the blossom buds expand repidy, the weevil is probably not able to cut so many buds because it works comparatively slowly. The following spring may be cold and rainy, and having more time, the injuries of the weevil may be much more noticeble.

\section{Netural Inemies}

To rear the paragites successfully, the buds must not be allowed to ary up, sinee the bude normally remain on the ground and keep moist. Two fera pots, one a little smaller, answered the purpose very well. The smaller one is placed with in the larger one so that the buttoma are opposite. The crevice is filled with sand and a oomstock vial used in the opening to collect the parasites as they come to the light. The whole is sunk in molst soll to keop the buds from drying out. 
Wr. Chittenden reports four parasites for tinis inseat - Dolyptus tib1ator. Braoon anthozomi, Catolooaus anthonomi, and C. 1noertug. None of these were resred from this loeslity. A number of buas were plaged in the breeding Jar on July 5th. A total of 419 weevils were reered and 184 parasites of which two are new speaies as reported by lir. Girsult \$8 follows:

Chelo1doldes

Gapelmus aoleopterophagus II.sp. E.'s Catolooous perdubius 11. 8p. $62 \delta^{\prime \prime s}$ and $457^{\circ} \mathrm{s}$ Habrocytue obsouripes Aah $11^{\circ}$ 's and $280^{\prime \prime s}$ Polynems oonsobremia Girault $1^{\circ}$ and $3^{\circ} \mathrm{g}$ Burytoms sp. 1 matilated 1 aminil enoyrtid

Ceoidomyldee

Lestodiplosis sp.

Uidge larvee were oceasionsily found within

the bude. The edulte are s speoies of Lestodiplosis, as determined by 1r. Z. P. Pelt. Nembers of this genus are predsaeout and possibly asavengers.

$$
\text { Leatodiplosis sp. - lervs - } 1 . \mathrm{E} \text { min. Long, }
$$

orange-red; sonewhat llattened and tspering to head ond whore the mouth perts are prominent. Ventrsl eurface of esoh abdominel segment covered with emnll tubercles and with two hairo projeotiag from each.

This gives s total of 31.3 per cent perssitism, as determined by rearing. 
Out of a total of 162 buds examined on July. I,

56 contained nothing

61 contained weevil larvae

46 contained parasites.

This gives 43 per cent parasitism of the buds which contained some lind of larva. Parasitic larvae were not found numerous until June 20 among which a very small larval parasite was often found. In a few instances lervae were found on some of the parasitic larvae.

Ordinarily, when a bud is opened, the larva strikes violently beck and forth. If, however, it is parasitized, it will remain motionless, altho it may look healthy, and apparently free from parastic larvae. Upon examination, a small parasitio larva may be found on the body, sucking the fuices. Altho only eggs of the parasites were often found on or near the weevil larva in a few cases, it already appeared dead.

$$
\text { Kany of the buds (about } 10 \text { or } 15 \text { per cent) }
$$

do not fall, but remein hanging. These are quite conspiouous beoause they turn brownish when they dry. Upon examination, about 50 per cent of them conteined larva, while in the others nothing was found probably aue to thetr having dried out. Many of the buds, upon falling to the ground are so covered with leaves that they remsin very moist, and altho in some instances, fungus threads were all thru the bud, the larva was apparently very healthy, showing that they oan withstend very moist conditions.

\section{Control.}

As the weerils only attack the staminate varieties the use of pistilate varieties would be an ideal method of con- 
trol. However, it is very difficult to get pietilate forms thet will be as satisfactory as the staminate ones, they being either shy bearers or else do not stand shipment.

The one-crop system is by all means one of the best methods of getting rid of the weevil because they hibernate within the old fields and do not disperse readiy. Professor Urosby in his book on Fruit Insects has the following to say in regard to strawberry growing:- "Strawberry growing is more akin to the raising of field orops than to the oultivation of other fruits. Ilkewise in the control of strawberry insects less reliance is placed on eprajing and more attention is given to crop rotation, fall plowing, clean oultivation, and similar practices The one orop system of strawberry culture as now practiced by the majority of commercial growers greatly simplifies the problem of insect control." All the old as well as the one-year-old fields, if bady infested, should be plowed under immediately after ploking and the next season started with new plants. There being no weevils in the new fields, they will be comparatively scarce. This one-crop method should be continued for one or two years until nothing is seen of the insect.

Trap Crops.- Mr. Ohittenden advises the use of early blooming varieties to attract the weevils in the early spring. A better method is to leave one or two rows of the old fleld, when plowing it up, and leaving it uncovered. Such plants were found to bloom three or four weeks ahead of the others. This is more advantageous than an early-blooming variety because many of the farmers do not know what the early blooming varieties 
are, and if they do, would not take the trouble to plant them. It is also advisable to keep the straw on as long as possible on the fields so that when the beetles emerge, the buds will be covered, and they will be forced to seek buds that are acoessible. That this might very readily take place is substantiated by the fact that the writer found one field where the straw had blown off, to be worse infested than a neighboring field where it was on longer. Covering of the beds.- The covering of the beds with light muslin is also advised by some during the period of injury by the weevil. This was tried and put up on May 15th but found unsatisfactory. The berries did not ripen sooner, and in frot the plants were found in poorer condition. This might possibly be due to having been on for over five weeke, which length of time was necessary on account of the wet, cold spring that prolonged the blossoming period and kept the bude from opening.

\section{Spraying.- Sprayine experiments were tried} out on a small scale in the spring as the weevils began to appear. Powdered lead arsenate and sweetened liquid lead arsenate were both tried but with no apparent sucoess.

From experiments cerried on against the cotton boll weeril, it was found that a diet of pollon is absolutely necessery for the formation of eggs. The females feed almost exclusively on pollen during oviposition, while it is probable that the males are the ones thet puncture the under side of the leaves, petals and stamens. Spraying them is useless at the 
time they are cutting the buds. It was found, however, that the new brood, upon emerging, eat the leaves readily, as desoribed, because they do not oriposit at that time. Spraying will be much more effective at this time if about half of the plants in each row are plowed up as is commonly done soon after picking, and the remainder sprayed.

Fencing.- Is the weevils do not fly very far or high, it seemed possible to keep them out by means of a fence. A wire screen fence about 2 feet high was put up accordingly on April 30th, on a plot of ground about 10 feet square. This was banked up with dirt around the bottom, and boarde placed on top of the wire. Tanglefoot was then smeared both on the top and under the boards, to see if the weevil will try to ely or orawl in. No weevils were found in the tanglefoot and none were observed on the fence. Buds were not found out within the enclosure until june 20th, when most of the blossoms had already opened.

\section{The Sulphur Arsenical Dust.- Some recent}

experiments by rrofessor Headlee of Ilew Jersey appear to have been successfully used as a repellent. It is planjed to give this material a thoro test this spring by conducting a series of experiments in fielde where the weevil is known to be. very injurious 


\section{BIBLIOGRAFHY OF THE STRAWBERRY WEEVII}

From 1897 - 1915. For references up to 1897, see Chittenden. References marked with an asterisk have not been verified.

Adams, C. I.

1907 Arkansas experiment Station, Bul. 92: 16.

Brief biologioal and economic notes on the strawberry weevil. Advises trap crops.

Britton, W. A.

1909 Conneoticut Agrioultural Bxperiment Station Report for the year 1908; p. 846

Brief notes on life history and habits. Injury reported from South Killingly and Huntington. Advises clean culture and the plantirg of pistilate varieties.

Caesar, I.

1913 Annual report of the Intomological Society of Ontar10; pp. $75-84$.

Reported as injurious at Brant county.

Card, G. W.

1903 Rhode Island Experiment Station, Bul. 91: 105.

Compiled notes on methods of control. In 1899 a patoh of wild blookberries near the college had 182 out of 291 buds destroyed.

Chittenden, F. H.

1903 U. S. Department of Agrioulture, Division of Entomology, Bul. 40: 120.

In Jurlous at Rose Hill, Wilnington, end Baltio, N. C., Bgrnevilie, Ind., Van Buren, Ark. 
Chittenden, F. H.

1898 Notes on the strawberry weovil, U. S. Dept. of $\mathbf{H r} \cdot$, Div. of Entomology. Bul. 10, N. S.; pp. 82 - 87 .

Its injuries and bibliography. Correspondents report apparent sucoess with Bordeaw and Faris green; olean cultivation and use of tobacoo dust and fertilizers.

Close, C. P. and Ballard, T. I.

1911 Maryland Agrioultural Experiment Station; Bul. 160: 280.

Advises clean cultivation and profusely blooming varieties.

Fletoher, J.

1906 Report of the Canadian Experimental Farme for 1905, p. 187 .

Report of injury at Clarkson, Ontario. Advises pistilate varieties; trap crops near outer rows Covering of plants Fas found to keep out bees that ald in fertilization.

*Fletcher, J.

1899-1900 Transetions of the Royal Society of Uanada 2nd ser. 5, pp. $207-231$.

Headlee, T. J.

1915 Report of the Entomologioal Dept. for 1914. p. 349.

More injurious than usual. 50 per cent loss reported often. Ifanhettan variety espeoielly susceptible. Pistillate varieties not in favor by farmers.

Headlee, T. J.

1916 New Jersey Agricultural Experiment Station;

Experiments with a mixture of sulphar and arsenate of lead powder reported sucoessful against the strawberry we $\nabla 11$ as a repellent.

Herrick, G. W.

1912 Iime and the Strawberry Weevil, Rural New Iorker, JuIy 13, p. 781 . 
Iime, ashes, dissolved bone, kerosene and plaster, and tobacoo dust found wanting. Some growers report sucoess with arsenate of lead.

Hitching 8 , E. F.

1906 First Annual Report of the State Entomologist.

Plants 1mported from New York found infested with the weevil and destrojed.

Houghton, C. 0 .

1904 Delaware Experiment Report for 1903, p. 158.

Brief report. Found practioally no weevils at Bridgefield where they were abundant the previous jear. Slight injury to M. C. A. Betts of Cannon, Del.

Johnson, W. G.

1897 U. S. Dept. of Agr., Div. of sint., Bul. 20; 64.

Reported injury to Fnhance and Lovett varieties from Alleghney Co., Washington Co., Blue Ridge Mts.

Lookhead, W.

1908 Annul Beport of the Entornological Society of Ontario 39 , p. $124-125$.

Iugger, 0.

1899 Fifth innual Report of the Antomologist, p. 199.

Found in limited numbers in State. Compiled notes on Life-historg and control

lîorril, A. W.

1907 The Strawberry Weevil in the South-oentral State U.S. Dept. of Agr., Bur. of Ent., Bul. 63; 57-62, Part 6.

Parasitism studied in connection with Anthonoma grandis. 10 - 15 per cont of buds in jured in Arkansas where parasitism was indicated.

Murtfeldt, M. E.

1900 Some insects infurious to small fruits. Report Missouri Horticultural Society, p. 318. 
Compiled notes on life history and habits. Advises use of Paris green.

O'Bane, W. C.

1914 Injurious Insects; how to Recognize and Control Them. p. 337 .

Recommends early spraying with lead arsenate and Paris green; also clean cultivation, burning over, and the use of pistillate varleties.

Datch, E. M.

1907 Maine Agricultural Experiment station. Bul. 148; 271

Found to be widely distributed, altho but a single large strawberry crop was destroyed, noar Farmington. The weevils were also collected on wild raspberry.

Pettit, R. H.

1906 Miohigan Agricultural Experiment Station. Bul. 244; 104 .

Economic notes. Advises olean oulture, trap crop of staminate varieties, arsenate of lead. Blackberries found bady infested at Arcadia.

Quaintance, A. I.

1905 intomological Notes from Maryland. U.S.Dept. of Agr. Div. of Entomology, Bul. 40; 49-50.

Reports 25 - 50 per cent injury - profusely blooming varieties proved atisfactory in escaping loss. Pistillate varieties not found satisfactory.

Qua intance, A. I.

1897 The Strawberry Weevil. Florida Agrioultural Experiment Station. Bul. 42: 597.

Does not oosur in Florida, but mentions its possible introduction. 
Sanderson, E. D.

1913 The Strawberry Weevil.

Insect Pests of Farm, Garden, and Orchard. p. 456. Advises pistillate varieties, trap crops, opraying with arsenate of lead, clean cultare.

Sanderson, E. D.

1903 Delфware Experiment Station

Report of the intomologist for 1902, p. 150

Reported as injurious sinoe 1898 at Bridgewater, espeoially noticeable on pistillate varieties and near woods. Suggests burning over of fields.

Senderson, E. D.

1902 U. S. Department of Agrioulture, Division of Entomology, Bul. 37; 102 .

Reported as excessively injurious sinoe 1898, ruining orop in some places. Considers a remedy for this pest of great value.

Slingerland, M. V. and Crosby, C. R.

1914 The Strawberry Weevil.

Manual of Fruit insects, p. 372.

Recommende pistillate varieties, trap crops, spraying with argenate of lead, clean oultivation.

Slingerland, M. V.

1908 Fighting the Strawberry Weevil, Rural New Yorker 67 : 804 .

Recommende covering of beds with muslin, cultivation of pistillate, trap orops, and combination of arsenate of lead, and Bordeaux mixture. 
Smith, J. B.

1911 N. J. Agrioultural Experiment Station

Report for the jear 1910, p. 308.

Hibernation habits studied - specimens were

found less in the strawberry fields than in

the rubbish around the edges. Not abundant

in any one place. Woods or scrub land near

by seems more attraotive then any rubbish

covered or moist protected locality.

Smith, J. B.

1912 N. J. Experiment Station; Report of the Entomologist for 1911, p. 412 .

Reports injury in Burlington, Camden and Glouces ted co. Mr. Blake working on a resistent variety.

Smith, J. B.

1909 Insects Injurious to Strawberries,

N. J. Agricultural Bxperiment Station, Bul. 225.

Iife history, habits ard control measures. Feconmends

Bordeaur and Faris green. Just before blossoming ( $4 \mathrm{lbs}$. of coper sulphate, 4 lbs. of lime, 50 gals. H20 with 1 lb. of Paris green. 25 lbs. of arsenate of lead to every $125 \mathrm{gal}$. of Dordeaux; also mowing and burning of vines as soon as ploking is over, covering of beds, pistillate varieties, clean oulture, trap crop and profusely blooming varieties. Does not advise mulching.

Smith, J. B.

1905 N. J. Experiment Station - Report of the Entomologist for the year 1904 .

Notes prevalence. Abundent at atlanta Co. and Southern States.

Smith, J. B.

1903 N. J. Experiment Station - Report of the Entomologist for the year 1902, p. 429.

Reported as injurious at Burlington and cumberland Co. 
Smith, J. B.

1898 N. J. Experiment Station. Report of the intomologist for $1897, p .402$.

Report of infury.

Sherman, F., Jr.

1909 Notes of the year. Journal of Economic Eintomology,

Vol. 2; 201 - 206.

Reported as again serious; pistillate varieties not popular beoause they are not early enough.

Sherman, F. and Collet, R. W.

1904 N. Carolina, Department of Agr., Div. of entomology, Circ. 12 .

Notes on appearance, life history and habits. Recommends the planting of imperfect varieties, the mowing and burning of fields immediately after picking, clean oulture, trap crops, and spraying with Bordeaux and Paris green. Io results were obtained with carbolic acid, and water, and whale oil soap.

Symons, T. B.

1904 Fntomological Notes of the Year in Maryland. U. S. Department of A riculture, Division of htomology. Bul. $46: 97$.

Report of injury.

Washourn, F. I.

1904 Ninth Rep rt of the Stete Entomologist, pp. 52 and 78 .

Advises spreying with Bordeaux and Paris greon; burning over of fields; planting of pistiliate verieties.

Washburn, F. I.

1903 Elghth Report of the State Entomologist, p. 151.

Report of injury. Advised the planting of pistillate forms. 
Febster, I. M.

1902 U. S. Department of Agriculture, Division of Eutomology Bul. 31: 85 .

Very injurious in Scioto County, Onto. Half of orop destroyed.

Webster, F. M.

1901 Beport of Committee on Entomology, Ohio Hortioultural Society, Repart of 1901, p. 878 .

Reported as injurious near Soloto, Ohio, and Portamouth, Ohio, at the farms of IIr. Welters and $W r$. Kenney. 50 per cent of orop destroged. 


\section{PIATE I.}

Fig. 1. The Strawberry Weevil at work outting a bud in which it had lald an egg; In order to protect the future grub.

rig. 2. Pedioel of Strawberry showing all of the buds out off by the strawberry Weevil. 
Plate 1
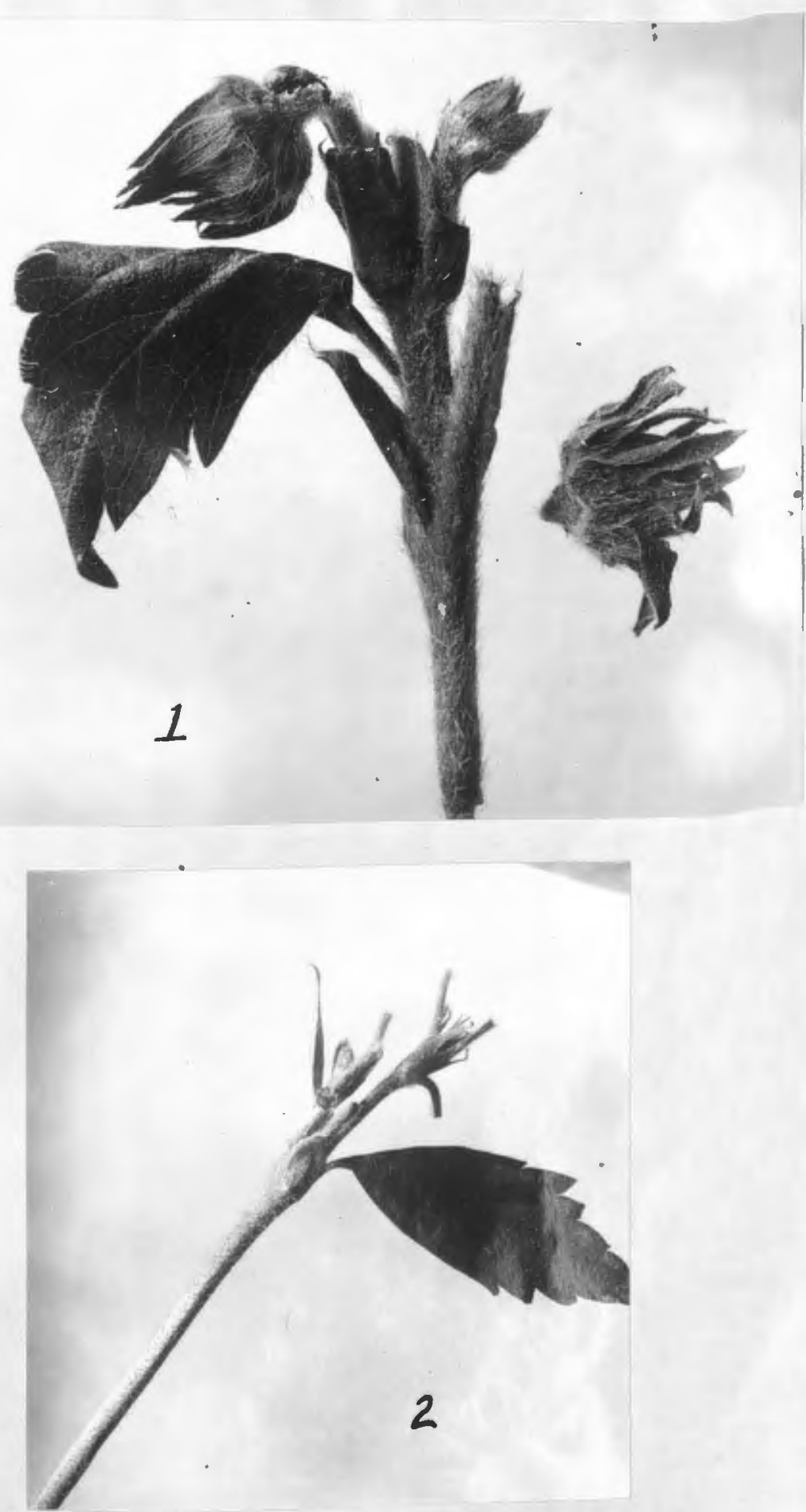

S. Marceriteh. 
F18. 1. Work of the Strawberry Weeviz on Raspberry buds showing the buds cut in a similar manner as on strawberry.

F1E. 2. Same as F1g. I - showing also work of the Raspberry Byturus on leap. 

PIATE III.

18. 1. Work of the Strawberry Weevil as 1t appears in the field, showing a number of buds cut

on a single plant. 


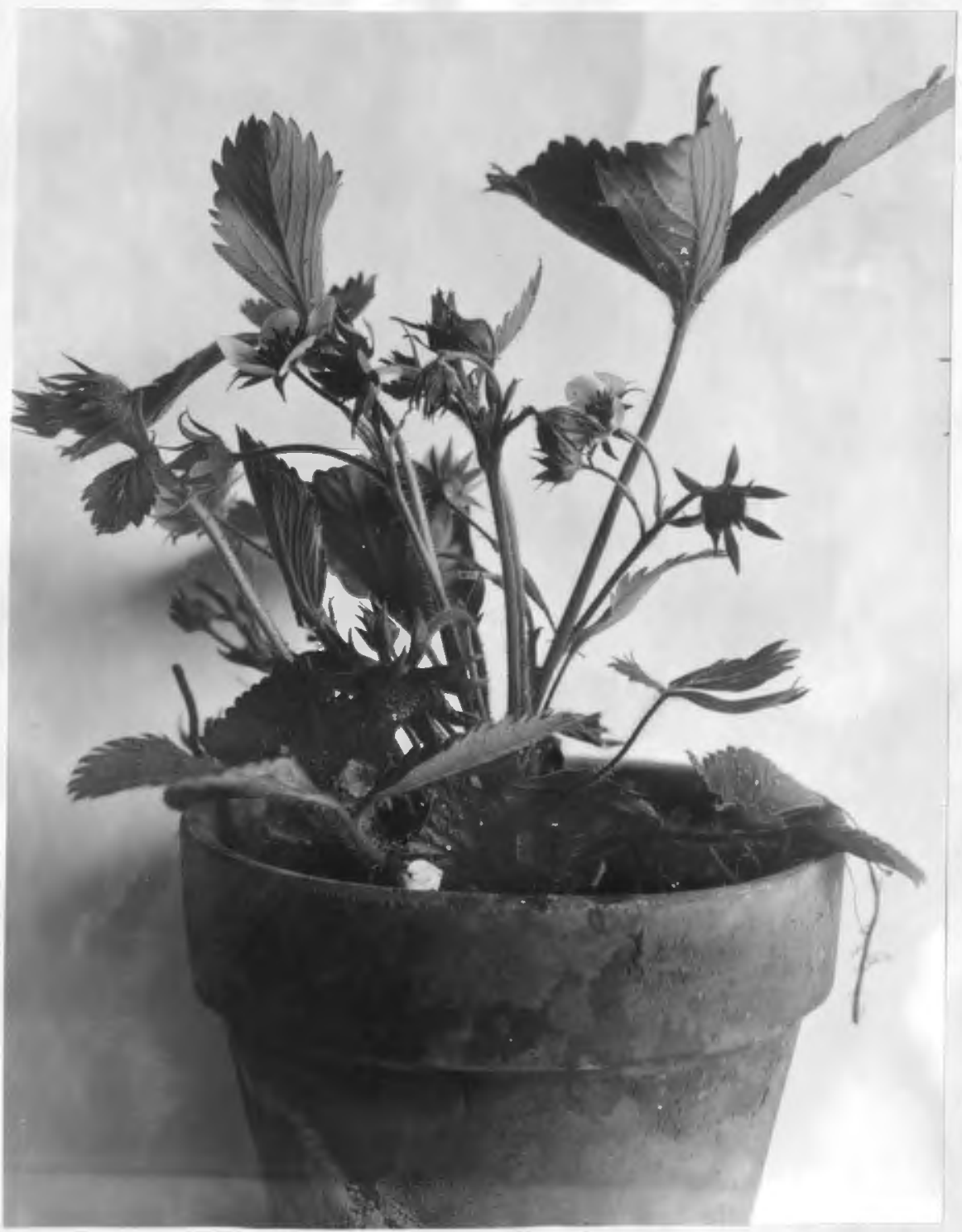

S. Mancorritch. 


\section{PIATE IV.}

Fig. 1. The Stramberry Woevil: Dorsal aspect of the adult, enlarged about seven times.

Pig. 2. The Strawberry Weevil: Lateral aspeot of the adult.

Fig. 3. The Strawberry Woevil: Antenna, (greatly enlarged)

Fig. 4. The Strawberry Weevil: Secondary sexual characters as indicated in the snout; female snout at left and mele snout at right, which is shorter and atouter than that of the female.

Iig. 5. The Strawberry Weevil: Hind wing (greatly enlargea). 


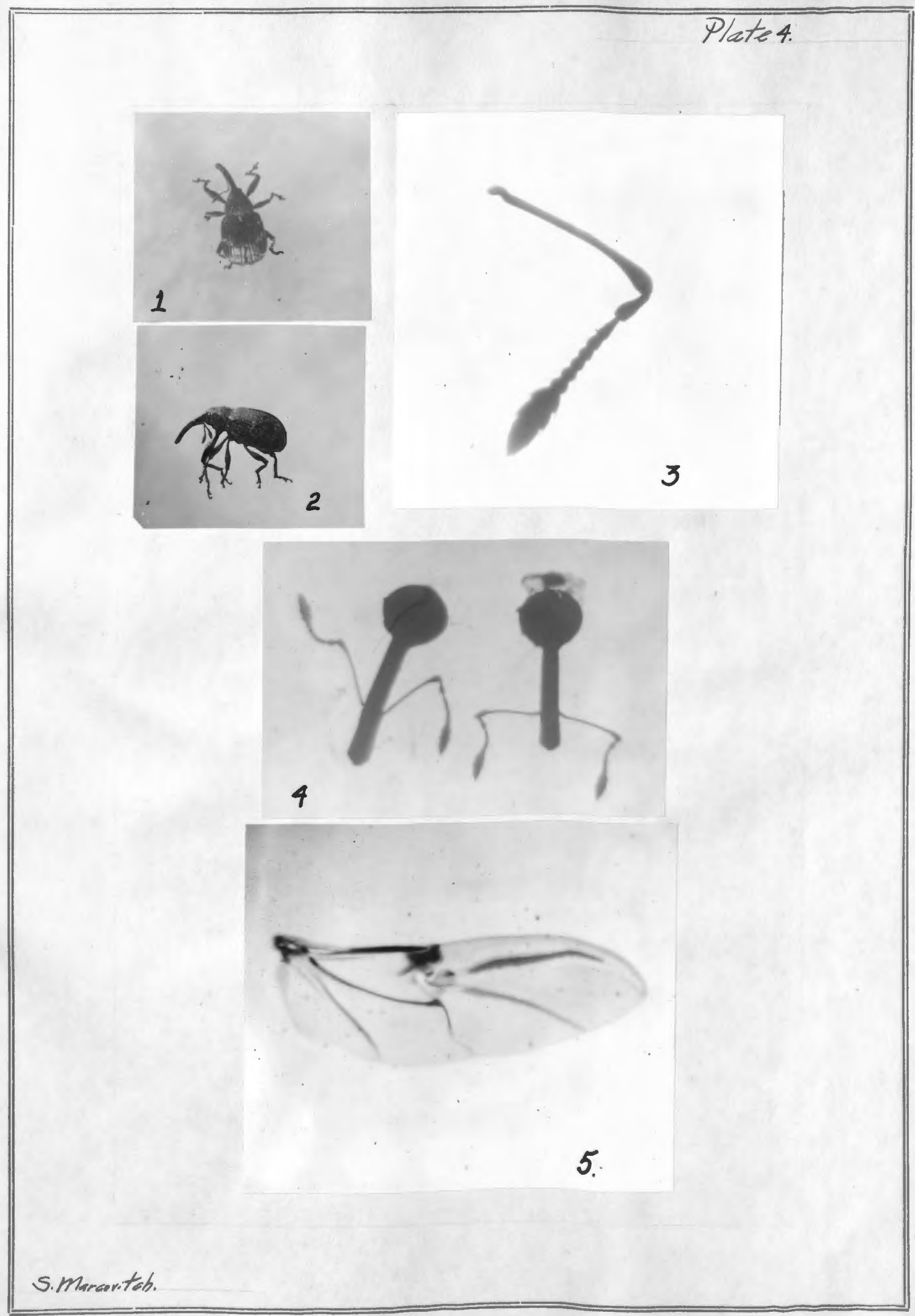




\section{Plete $\nabla$.}

Fig. 1. The strawberry Weevil: Bud opened showing egg (enlerged about seven timeg).

F1g. 2. The Strawbery Weev11: Young grub just after hatching from egg (left). Egg (on right).

F18. 3. The Strawberry Weevil: Bud opened showing the mature curved grub. Pollen and contents of bud eaten up.

T18. 4. The Strawberry Weev11: Grubs getting ready to pupate, being about 22 days old.

Fig. 5. The Strawberry Weevil: Pupa.

F18. 6. The Strawberry Weevil: A dried strawberry bud showing emergence hole of the adult. 

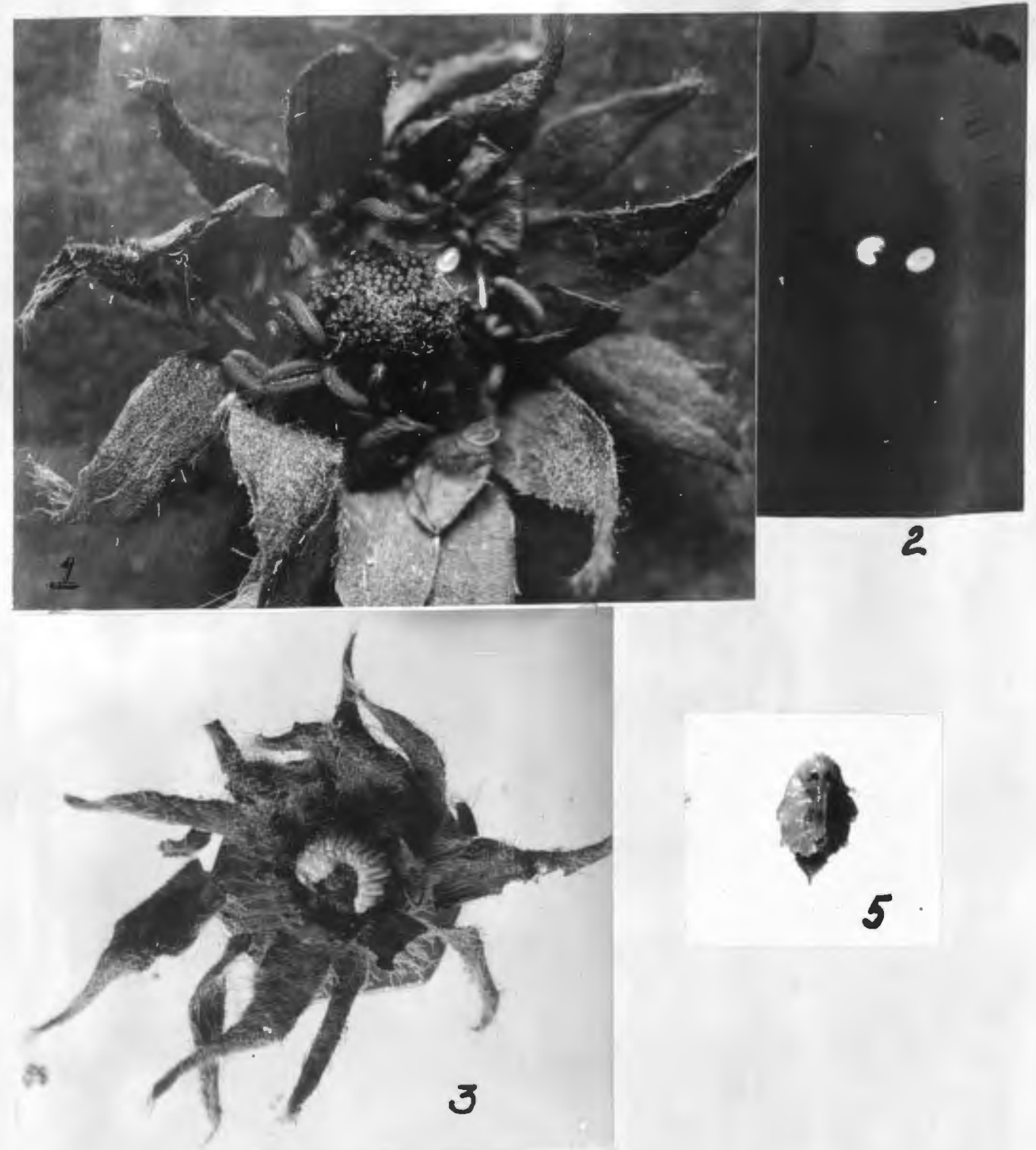

5
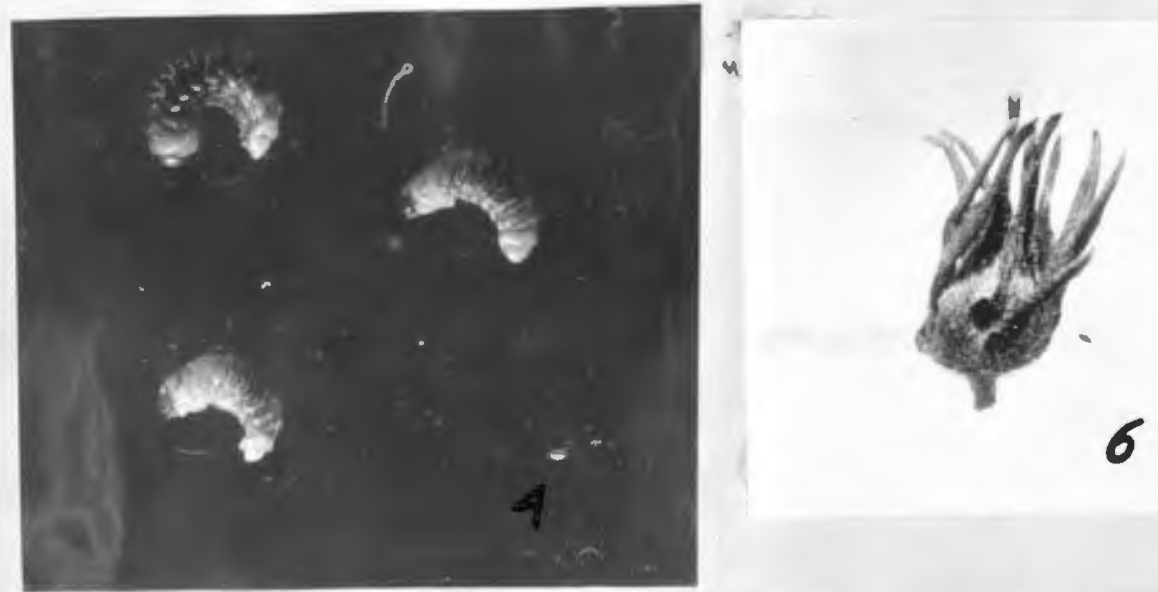

s.manesitch. 


\section{PIATE VI.}

Fig. 1. The Strawberry Weevil: leaf of strawberry showing feeding punctures on the under side (August 19̆15).

Fig. 2. The Strawberry Weevil: Strawberry leaf showing parts of leaf fallen out where feeding punctures have been numerous.

Fig. 3. The Strawberry Weevil: Work on fruit. 


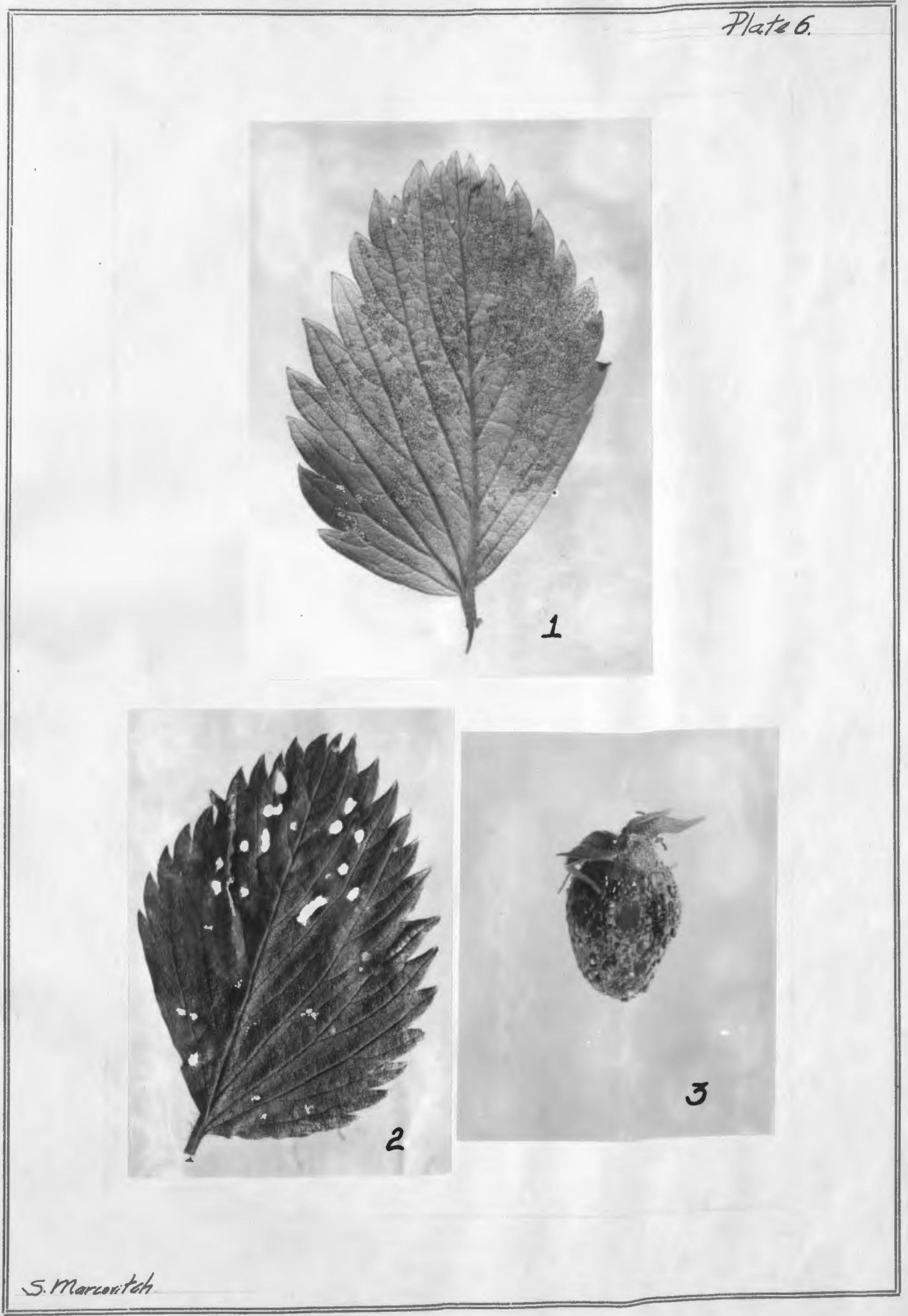




\section{PIATE VII.}

F1g. 1. The Strawbery Weev11: Head of larva, Dorsal aspect with parts named. (Much enlarged).

F18. 2. The Strawberry Weevil: Ventral aspect of laxilia and labium of the larva with parts named. (Niuch enlerged).

F1g. 3. The Strawberry Neevil: Mouth parts of the adult, ventral aspect with parta named. (Trach enlerged).

F18.4. The Strawberry Weevil: Ovipositor as 

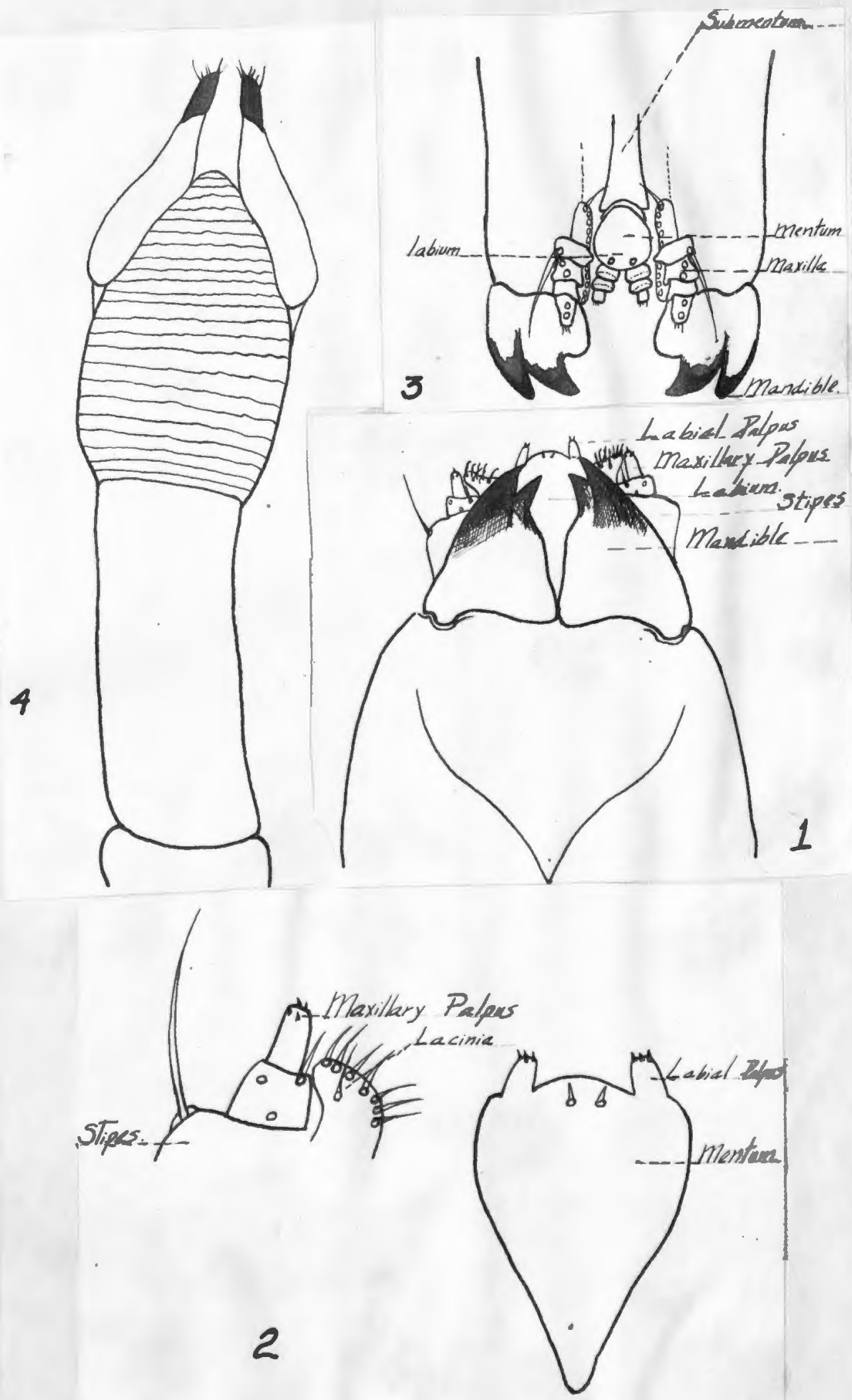

5. Marcovitch. 